\title{
Frequency of Human Toxocariasis in Jos, Plateau State, Nigeria
}

\section{OO Ajayi ${ }^{+}$, DD Duhlinska, SM Agwale, M Njoku}

Applied Parasitology Laboratory, Department of Zoology, University of Jos, Jos, Nigeria

The enzyme-linked immunosorbent assay (ELISA) was used to examine sera of 104 children and adults in Jos, Plateau State, Nigeria for anti-toxocaral antibodies, out of which 31 (29.8\%) were reactive.

The seropositive rates were $30.4 \%$ for adults, $29.6 \%$ for children, $34 \%$ for females and $25.9 \%$ for males. However, the differences were not significant by age and sex. A highly significant association ( $p$ $<0.001)$ was observed between seropositivity and geophagia but none between seropositivity and dog ownership $(p>0.05)$.

Key words: seroprevalence - Toxocara - enzyme-linked immunosorbent assay - Nigeria

Toxocara canis is a saprozoonotic parasite capable of infecting man. Infection in man follows the ingestion of embryonated eggs of the parasite with subsequent hatching and migration of the larvae in his tissues. The persistence or migration of T. canis in the tissues of man causes visceral larva migrans, VLM (Beaver 1969).

The diagnosis and confirmation of human toxocariasis rely heavily upon serological tests. In this respect the enzyme-linked immunosorbent assay (ELISA) developed by Cypess et al. (1977) and modified by Glickman et al. (1978) has been found to be very useful in different parts of the world (De Savigny et al. 1979, Glickman et al. 1979, Matsumura \& Endo 1983, Garcia et al. 1989, Abo-Shehada et al. 1992, Hakim et al. 1992, Chomel et al. 1993, Holland et al. 1995) because of its high sensitivity and specificity in the routine diagnosis of human toxocariasis.

The purpose of this paper is to report on the first serological diagnosis of human toxocariasis in Nigeria and the importance of the disease as a public health problem in the tropical environment.

\section{MATERIALS AND METHODS}

Serum samples - The sera of 104 subjects comprising of 54 males and 50 females, aged between 2 and 24 years were collected between June 28 and July 4 1996. Twenty two of the subjects (15

This work was supported in part by the Faculty of Natural Sciences, University of Jos, research grant no. UJ/ FNS/RG/94-95/13.

${ }^{+}$Corresponding author. E-mail: ajayi j @ unijos.edu.ng Received 6 April 1999

Accepted 11 November 1999 males and 7 females) were inpatients of the Jos University Teaching Hospital, 58 (29 males and 29 females) were pupils of the Jos University Primary School, 15 (5 males and 10 females) were students of the Jos University Demonstration Secondary School, and 9 (5 males and 4 females) were volunteers. Before the collection of sera, signed consent were obtained from the subjects or their parents or guardians. Information about geophagia (soil pica) and dog ownership were obtained by direct interrogation of the subjects and or their parents or guardians. Six of the subjects had parasitological proven helminthiasis which included ascariasis, taeniasis, trichuriasis and hookworm infections.

After collection, serum samples were stored at $-20^{\circ} \mathrm{C}$ until required.

Positive and negative control sera and Toxocara ES antigen were gifts from Dr Guus Van der Lugt, Institute of Infectious Diseases and Perinatal Screening, Bilthoven, The Netherlands.

The ELISA - The ELISA was carried out in two 96 well polystyrene microtitre plates (Maxisorb, Nunc, Weisbaden, Germany). An amount of 100 $\mu \mathrm{l}$ of the antigen diluted 1:30 in carbonate buffer, $\mathrm{pH} 9.6$ was added to each well. Then the plates were left opened and incubated overnight at $37^{\circ} \mathrm{C}$. The plates were washed five times with phosphate buffered saline (PBS) containing $0.05 \%$ Tween 20 (PBST). After discarding the washing fluid, 100 $\mu \mathrm{l}$ of the blocking solution (1\% BSA) (Sigma, St. Louise, USA) were added to each well and incubated at $37^{\circ} \mathrm{C}$ for $1 \mathrm{~h}$. The plates were washed as described above. Then, $100 \mu \mathrm{l}$ of a test serum diluted 1:40 in PBS containing 0.05\% Tween 20 were added to each well. Also included in each plate were one positive and three replicates of the negative control sera at the same dilution with the test 
sera. The plates were then incubated again at $37^{\circ} \mathrm{C}$ for $1 \mathrm{~h}$. Bound antibodies were detected by the addition of $50 \mu \mathrm{l}$ of secondary anti-human IgG conjugated to alkaline phosphatase (Murex diagnostic Laboratory, England) to each well. The plates were covered and incubated at $37^{\circ} \mathrm{C}$ for $30 \mathrm{~min}$. The plates were then washed three times as described above. Staining was carried out with $50 \mu \mathrm{l}$ of NADP (Murex) for $20 \mathrm{~min}$ at $37^{\circ} \mathrm{C}$. Then 100 $\mu l$ of the amplifier solution (Murex) was added to each well for $10 \mathrm{~min}$ at room temperature. The reaction was stopped by the addition of $50 \mu \mathrm{l}$ of $2 \mathrm{M}$ $\mathrm{H}_{2} \mathrm{SO}_{4}$ to each well. Optical density was measured with a spectrophotometre at $405 \mathrm{~nm}$. The cut-off level was determined from the OD values of three negative control sera using the formula $(0 \times 3$ SD x 2) (Rachanee et al. 1994).

The chi-square and the Spearman rank correlation were used in the analyses of data.

\section{RESULTS}

Out of the 104 human sera examined, 31 $(29.8 \%)$ were reactive for anti-toxocaral antibodies, including $14(25.9 \%)$ of 45 and $17(34.1 \%)$ of 50 sera of the male and female subjects respectively (Table I). There was no significant differ-
TABLE I

Overall seroprevalence of human toxocariasis in Jos, Plateau State, Nigeria

\begin{tabular}{lccc}
\hline Sex & No. examined & No. positive & $\%$ prevalence \\
\hline Male & 54 & 14 & 25.9 \\
Female & 50 & 17 & 34 \\
\hline Overall & 104 & 31 & 29.8 \\
\hline
\end{tabular}

ence between the seropositive rates in the males and females ( $p>0.05)$.

Table II shows the seroprevalence of human toxocariasis by age and sex. Of the 81 sera of children, $24(29.6 \%)$ were positive and the seropositive rates for male and female subjects of this age group were $25 \%$ and $35.1 \%$ respectively. Out of the 23 sera of adults 7 (30.4\%) were positive, and seropositivity ranged from 30 to $30.8 \%$ between the males and females. However, there were no significant differences between the age groups and between both sexes ( $p>0.05$ ).

A highly significant association $(\mathrm{p}<0.001)$ was observed between seropositivity and geophagia (Table III), but none between seropositivity and dog ownership ( $\mathrm{p}>0.05)$ (Table IV).

TABLE II

Seroprevalence of human toxocariasis by age and sex in Jos, Plateau State, Nigeria

\begin{tabular}{|c|c|c|c|c|c|c|}
\hline \multirow[b]{2}{*}{ Sex } & \multicolumn{3}{|c|}{ Children $<15$ year } & \multicolumn{3}{|c|}{ Adults $\geq 15$ years } \\
\hline & $\begin{array}{c}\text { No. } \\
\text { examined }\end{array}$ & $\begin{array}{c}\text { No. } \\
\text { positive }\end{array}$ & $\begin{array}{c}\% \\
\text { prevalence }\end{array}$ & $\begin{array}{c}\text { No. } \\
\text { examined }\end{array}$ & $\begin{array}{c}\text { No. } \\
\text { positive }\end{array}$ & $\begin{array}{c}\% \\
\text { prevalence }\end{array}$ \\
\hline Male & 44 & 11 & 25 & 10 & 3 & 30 \\
\hline Female & 37 & 13 & 35 & 13 & 4 & 30.8 \\
\hline Overall & 81 & 24 & 9.6 & 23 & 7 & 30.4 \\
\hline
\end{tabular}

TABLE III

Relationship between seropositivity of human toxocariasis and geophagia in Jos, Plateau State, Nigeria

\begin{tabular}{lcccccc}
\hline Sex & $\begin{array}{c}\text { No. with } \\
\text { geophagia }\end{array}$ & $\begin{array}{c}\text { No. with } \\
\text { toxocariasis }\end{array}$ & $\begin{array}{c}\% \\
\text { prevalence }\end{array}$ & $\begin{array}{c}\text { No. without } \\
\text { geophagia }\end{array}$ & $\begin{array}{c}\text { No. with } \\
\text { toxocariasis }\end{array}$ & $\begin{array}{c}\% \\
\text { prevalence }\end{array}$ \\
\hline Male & 19 & 10 & 52.6 & 35 & 4 & 11.4 \\
Female & 31 & 14 & 45.2 & 19 & 3 & 15.8 \\
\hline Overall & 50 & 24 & 48 & 54 & 7 & 13 \\
\hline
\end{tabular}

TABLE IV

Relationship between seropositivity of human toxocariasis and dog ownership in Jos, Plateau State, Nigeria

\begin{tabular}{lcccccc}
\hline Sex & $\begin{array}{c}\text { No. of dog } \\
\text { owners }\end{array}$ & $\begin{array}{c}\text { No. with } \\
\text { toxocariasis }\end{array}$ & $\begin{array}{c}\% \\
\text { prevalence }\end{array}$ & $\begin{array}{c}\text { No. of non } \\
\text { dog owners }\end{array}$ & $\begin{array}{c}\text { No. with } \\
\text { toxocariasis }\end{array}$ & $\begin{array}{c}\% \\
\text { prevalence }\end{array}$ \\
\hline Male & 36 & 8 & 22.2 & 18 & 6 & 33.3 \\
Female & 23 & 7 & 30.4 & 27 & 10 & 37 \\
\hline Overall & 59 & 15 & 25.4 & 45 & 16 & 35.6 \\
\hline
\end{tabular}




\section{DISCUSSION}

The present work reports for the first time serological proven human toxocariasis in Nigeria. The $29.8 \%$ human toxocariasis reported in the present study shows that the disease is a zoonotic problem in the study area. The result compares with the $31.9 \%$ reported by Hakim et al. (1992) in Malaysia.

With respect to ELISA serology for T. canis it has been observed that antibodies can persist for many years following initial infection (Glickman \& Schantz 1981). The higher seropositivity observed in adults than in children in the present study may be attributed to infection during childhood, since all adult subjects confessed to engaging in geophagia during childhood only.

The seropositive rates of $25.4 \%$ and $35.6 \%$ recorded in dog owners and non-owners of dogs respectively in the present study suggest that these two groups are equally at risk of being infected. The results are in line with that of Woodruff et al. (1978) who observed that $50 \%$ of patients with clinical toxocariasis had never owned a dog or cat or had close contact with pets. The present result further suggests that toxocaral infection in the study area is acquired by the ingestion of soil containing infective eggs and confirms an earlier report by Ajayi and Duhlinska (1998) that there is widespread contamination of the environment in Jos with Toxocara eggs.

The sera of the six subjects who had other helminthic infections were not reactive for anti-toxocaral antibodies. The absence of significant cross-reactivity in these sera confirms the high specificity of the Toxocara ES antigen in detecting anti-toxocaral antibodies and its usefulness in a tropical region like Nigeria, where multiple helminthic infections are common and can complicate the interpretation of less specific serological tests (De Savigny et al. 1979, Speiser \& Gottstein 1984).

It was observed during the course of this study that there was generally a high level of ignorance about the public health hazards posed by dog parasites. Therefore, there is a need for public health enlightenment campaigns to educate the populace on these hazards and a more responsible dog ownership.

\section{ACKNOWLEDGEMENTS}

To Dr Guus Van der Lugt of the Institute of Infectious Diseases and Perinatal Screening, Bilthoven, The Netherlands, for the provision of control sera and Toxocara ES antigen. To Drs I Angyo, C Okolo, E Ikeh and Mr IG Dakat all of the University of Jos Teaching Hospital, for helping with the collection of blood from patients and to Mr J Dadick of the Plateau Hospital Jos, for technical assistance.

\section{REFERENCES}

Abo-Shehada MN, Sharif L, el-Sukhon SN, Abuharfiel N, Atmen RF 1992. Seroprevalence of Toxocara canis antibodies in human in Jordan. J Helminthol 66: 75-78.

Ajayi OO, Duhlinska DD 1998. Distribution of Toxocara eggs in different soil types in Jos and DutseKura, Plateau State, Nigeria. Science Forum 1: 3137.

Beaver PC 1969. The nature of visceral larva migrans. J Parasitol 55: 3-12.

Cypess RH, Karol MH, Zidian JL, Glickman LT, Gilthin R 1977. Larva specific antibodies in patients with visceral larva migrans. J Inf Dis 135: 633-640.

Chomel BB, Katsen R, Adams C, Lambillothe D, Theis J, Goldsmith R, Koss J, Chionino C, Widjan DP, Sutisna P 1993. Serosurvey of some major zoonotic infections in children and teenagers in Bali, Indonesia. Southeast-Asia J Trop Med Pub Hlth 24: 321326.

De Savigny DH, Voller A, Woodruff AW 1979. Toxocariasis: serological diagnosis by enzyme immunoassay. J Clin Pathol 32: 284-288.

Garcia LC, Alvarez AM, Martin FS 1989. Epidemiological studies on toxocariasis and visceral larva migrans in a zone of Western Spain. Ann Trop Med Parasitol 83: 615-620.

Glickman LT, Schantz PM 1981. Epidemiology and pathogenesis of zoonotic toxocariasis. Epid Rev 3: 230-250.

Glickman LT, Schantz PM, Cypess RH 1979. Epidemiological characteristic and clinical findings in patients with serological proven toxocariasis. Trans $R$ Soc Trop Med Hyg 73: 254-258.

Glickman LT, Schantz PM, Dombroske RL, Cypess RH 1978. Evaluation of serodiagnostic tests for visceral larva migrans. Am J Trop Med Hyg 27: 492-498.

Hakim SL, Mak JW, Lam PI, Nazma S, Normaznah Y 1992. Seroprevalence of Toxocara canis among Orang Asli (aborigines) in Peninsular Malaysia. Southeast-Asian J Trop Med Pub Hlth 23: 493-496.

Holland CV, O'Lorcain P, Taylor MR, Kelly A 1995. Seroepidemiology of toxocariasis in school children. Parasitology 110: 535-545.

Matsumura K, Endo R 1983. Seroepidemiological study on toxocaral infection in man by ELISA. $J$ Hyg 90 : 61-65.

Rachanee CP, Simon L, David C, Pontiano K, Simon B, Jonathan W, and the WHO Network for HIV Isolation and Characterization 1994. Serotyping HIV type 1 antibody binding to the $\mathrm{V}_{3}$ loop: relationship to viral genotype. Aids Res Hum Retrov 10: 13791386.

Speiser F, Gottstein B 1984. A collaborative study on larval excretory/secretory antigens of Toxocara canis for the immunodiagnosis of human toxocariasis with ELISA. Acta Trop 41: 361-372.

Woodruff AW, De Savigny D, Jacobs DE 1978. Study of toxocaral infection in dog breeders. $\mathrm{Br}$ Med $\mathrm{J} 2$ : 1747-1748. 